\title{
PENGARUH KEPEMIMPINAN DAN MOTIVASI KERJA TERHADAP KINERJA APARATUR SIPIL NEGARA DI LEMBAGA PEMASYARAKATAN KELAS IIA MANADO
}

\section{THE INFLUENCE OF LEADERSHIP AND WORK MOTIVATION ON THE PERFORMANCE OF STATE CIVIL PERSONNEL IN THE IIA MANADO CLASS PENITENTIARY}

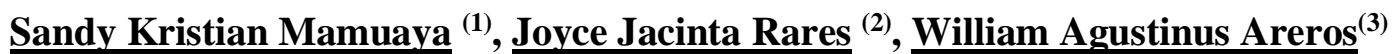

\author{
1) Mahasiswa Program Studi Pengelolaan Sumberdaya Pembangunan, Program Pascasarjana \\ Universitas Sam Ratulangi, Manado \\ 2) Dosen Program Program Studi Pengelolaan Sumberdaya Pembangunan, Program Pascasarjana \\ Universitas Sam Ratulangi, Manado \\ *Penulis untuk korespondensi: sandymamuaya44@gmail.com
}

$\begin{array}{ll}\text { Naskah diterima melalui e-mail jurnal ilmiah agrisosioekonomi@unsrat.ac.id } & \text { : Sabtu 16 Januari } 2021 \\ \text { Disetujui diterbitkan } & : \text { Minggu, 24 Januari 2021 }\end{array}$

\begin{abstract}
The Studi aims to know the effects of leadership and work motivation on the performance of state civil personnel in the IIA Manado class penitentiary. The study runs from July to November 2020 in the II A Manado class penitentiary. The population will sample it. The data-gathering technique in the study using a questionnaire or angket. Analisis data techniques use normality tests, heterosity tests, and regression analysis on linear berganda. Research shows that the fist leadership affects a positive performance on a state's civilian performance in a classroom correctional institution IIA Manado with a 0.0034 coefficient value of regression, so the better leadership then the better performance. Both job motivations affect positive performance on the performance of state civil personnel in the IIA Manado class correctional institution with the value coefficient regression of 0.742 so the better work motivation would be. ${ }^{*}$ prm*
\end{abstract}

Keywork : leadership impact, performance

\begin{abstract}
ABSTRAK
Penelitian ini bertujuan untuk mengetahui pengaruh kepemimpinan dan motivasi kerja terhadap kinerja aparatur sipil negara. Penelitian ini di mulai dari bulan Juli sampai dengan November 2020 di Lembaga Pemasyarakatan Kelas IIA Manado. Populasi pada penelitian ini adalah seluruh Aparatur Sipil Negara (ASN) di Lembaga Pemasyarakatan Kelas IIA Manado yaitu sebanyak 100 responden dan populasi tersebut menjadi sampel dalam penelitian ini. Teknik pengumpulan data dalam penelitian ini dengan menggunakan kuesioner atau angket. Teknik analisis data menggunakan uji normalitas, uji heteroskedastisitas, dan analisis regresi linier berganda. Hasil penelitian menunjukkan bahwa, pertama, kepemimpinan berpengaruh positif terhadap Kinerja Apatur Sipil Negara di Lembaga Pemasyarakatan Kelas IIA Manado dengan nilai koefisien regresi 0.034, sehingga semakin baik kepemimpinan maka akan semakin baik kinerja Aparatur Sipil Negara. Kedua, motivasi kerja berpengaruh positif terhadap Kinerja Aparatur Sipil Negara di Lembaga Pemasyarakatan Kelas IIA Manado dengan nilai koefisien regresi 0,742, sehingga semakin baik motivasi kerja maka akan semakin baik kinerja. ${ }^{* e p r m}{ }^{*}$
\end{abstract}

Kata kunci : dampak, kepemimpinan, motivasi, kerja, kinerja

Agrisosioekonomi : Jurnal Transdisiplin Pertanian (Budidaya Tanaman, Perkebunan, Kehutanan, Peternakan, Perikanan Ekonomi dan Teknologi Pangan serta Teknologi Pertanian). 


\section{PENDAHULUAN}

\section{Latar Belakang}

Mendukung tercapaianya tujuan organisasi diperlukan peran seorang pemimpin yang mampu menerima kritikan dan masukan untuk kemajuan organisasi yang dipimpinnya. Pimpinan Lapas Kelas IIA Manado di masa Pandemi Covid-19 untuk pelaksanaan rapat/ briefing tidak dilakukan secara berkala kepada petugas staf ataupun pengamanan sehingga dalam penyampaian masukan terhadap masalahmasalah yang dihadapi tidak dapat diselesaikan secara cepat, juga kurangnya kontrol pimpinan yaitu masih adanya pegawai yang tidak mengisi jurnal harian secara berkala, ketidakhadiran dalam apel pegawai staf dan pengamanan dan kurangnya kedisipilinan pegawai dalam keseragaman pegawai dan kelengkapan atribut yang digunakan serta kurangnya pemahaman pegawai tentang aplikasi-aplikasi yang digunakan dalam kedinasan seperti Sistem Informasi Kepegawaian, Sistem Informasi Surat Masuk dan Keluar, Laporan Harta Kekayaan Aparatur Sipil Negara dan E-Learning Kemenkumham.

Kesempatan untuk meningkatkan pengetahuan dan kompetensi menjadi hal yang penting untuk memotivasi pegawai dalam bekerja, namun untuk mendukung hal ini kurang diadakannya pengusulan mutasi internal bagi pejabat hal ini dapat mengakibatkan kejenuhan bagi pegawai karena rutinitas pekerjaan yang sama dilakukan setiap harinya, yang sebenarnya hal ini sangat baik untuk dilakukan agar dapat membekali pegawai dengan pengetahuan yang baru dan mendapat sarana untuk mengembangkan diri. Hal lain juga yang dapat memotivasi pegawai dalam bekerja yaitu ketersediaan sarana dan prasarana yang memadai namun didapati masih adanya pegawai yang menggunakan laptop pribadi untuk melakukan pekerjaan dan juga tidak tersedianya fasilitas pendukung lainnya seperti halnya bagian Humas yang masih menggunakan fasilitas pribadi dalam menjalankan tugas (DIM Lapas Manado, 2020).

Memberikan motivasi bagi pegawai juga dapat dilakukan dengan pemberian pemberian reward dan punishment bagi pegawai, namun pada kenyataan yang ada pemberian reward tidak dilakukan secara berkala dan penilaian secara subjektif serta bentuk pemberian reward tidak menarik perhatian pegawai untuk meningkatkan kinerjanya karena hanya berupa piagam penghargaan dan untuk punishment bagi pegawai yang berkinerja kurang baik tidak pernah dilaksanakan serta untuk melaksanakan tugas di luar kantor/tugas luar kurangnya anggaran untuk dana opersional perjalanan dinas pegawai.

Pada Tahun 2019 Lembaga Pemasyarakatan Kelas IIA Manado yang merupakan satu-satunya Unit Pelaksana Teknis (UPT) Pemasyarakatan di Sulawesi Utara yang melakukan pembangunan Zona Integritas Menuju Wilayah Bebas dari Korupsi (WBK), namum ditahap penilaian eksternal dari Kementerian Pendayagunaan Aparatur Sipil Negara (Kemenpan RB) Lapas Kelas IIA Manado belum berhasil mendapatkan Predikat Wilayah Bebas dari Korupsi (WBK) dikarenakan 6 Area Perubahan Manajemen Perubahan, Penataan Tatalaksana, Penataan Sistem Manajemen Sumber Daya Manusia, Penguatan Akuntabilitas Kinerja, Penguatan Pengawasan, dan Peningkatan Kualitas Pelayanan Publik belum termaksimalkan dengan baik. Berdasarkan hasil penilaian nilai Indeks Pelayanan Publik (IPP) dan Indeks Persepsi Anti Korupsi (IPAK) masih dibawah standar yang ditetapkan, hal ini menunjukan bahwa kurangnya komitmen dan kinerja dari Pimpinan untuk memberikan motivasi kepada Pegawai Lapas Kelas IIA Manado dalam upaya mewujudkan Zona Integritas menuju Wilayah Bebas dari Korupsi (WBK) (KemenPanRB, 2019). Pada Tahun 2020 Lembaga Pemasyarakatan Kelas IIA Manado kembali di usulkan untuk melaksanakan Pembagunan Zona Integritas Menuju Wilayah Bebas dari Korupsi (WBK) dan pada tanggal 12 Juni 2020 Lapas Manado menjadi salah satu Unit Pelaksana Teknis yang berhasil lulus dalam penilaian Tim Penilai Internal dari Inspektorat Kekemnterian Hukum dan HAM. Tapi dari nilai yang dimiliki Lapas Kelas IIA Manado memperoleh nilai lebih rendah dari yaitu 77,57 sedangkan pada Tahun 2019 88,26 yang disertai dengan beberapa catatan terkait dengan melengkapi data dukung dokumen dan inovasi terkait dengan pelayanan kepada masyarakat dan pegawai (Itjen Kemenkumham, 2020). 
Berdasarkan permasalahan serta data yang diperoleh dari pengamatan sementara di lapangan maka peneliti ini mengetahui / meneliti lebih jauh tentang kepemimpinan dan motivasi kerja terhadap kinerja dari aparatur sipil negara yang ada di Lembaga Pemasyarakatan Kelas IIA Manado.

\section{Dasar Hukum}

1. Undang - Undang Republik Indonesia Nomor 12 Tahun 1995 tentang Pemasyarakatan (Lembaran Negara Republik Indonesia Tahun 1995 Nomor 77, Tambahan Lembaran Negara Republik Indonesia Nomor 3614).

2. Undang - Undang Republik Indonesia Nomor 5 Tahun 2014 tentang Aparatur Sipil Negara (Lembaran Negara Republik Indonesia Tahun 2014 Nomor 6, Tambahan Lembaran Negara Republik Indonesia Nomor 5494).

3. Peraturan Pemerintah Nomor 30 Tahun 2019 tentang Penilaian Kinerja Pegawai Negeri Sipil (PNS).

4. Peraturan Menteri Hukum dan Hak Asasi Manusia Republik Indonesia Nomor M.HH05.OT.01.01 Tahun 2011 tetang Perubahan Atas Keputusan Menteri Kehakiman Nomor M.01-PR.07.03 Tahun 1985 tentang Organisasi dan Tata Kerja Lembaga Pemasyarakatan.

5. Peraturan Menteri Hukum dan Hak Asasi Manusia Republik Indonesia Nomor 20 Tahun 2017 tentang Kode Etik dan Kode Perilaku Pegawai Kementerian Hukum dan HAM.

\section{Rumusan Masalah}

Berdasarkan permasalahan diatas, maka rumusan masalah dalam penelitian ini adalah "apakah ada pengaruh antara kepemimpinan dan motivasi kerja terhadap kinerja aparatur sipil negara di Lembaga Pemasyarakatan Kelas IIA Manado?"

\section{Tujuan Penelitian}

Penelitian ini bertujuan untuk mengetahui pengaruh kepemimpinan dan motivasi kerja terhadap kinerja aparatur sipil negara di Lembaga Pemasyarakatan Kelas IIA Manado.

\section{Manfaat Penelitian}

Manfaat dari penelitian ini adalah

\section{Manfaat Teoritis}

Hasil dari penelitian ini akan memberikan kontribusi terhadap pengembangan ilmu pengetahuan khususnya untuk pengembangan ilmu administrasi publik.

\section{Manfaat Praktis}

Hasil penelitian ini dapat menjadi masukan atau kontribusi bagi Lembaga Pemasyarakatan Kelas IIA Manado tentang bagaimana kepemimpinan dan motivasi kerja itu berpengaruh terhadap kinerja para aparatur sipil negara.

\section{METODE PENELITIAN}

\section{Lokasi dan Waktu Penelitian}

Lokasi dalam penelitian ini di Lembaga Pemasyarakatan Kelas IIA Manado telah dilaksanakan pada bulan Juli sampai dengan November 2020.

\section{Jenis Penelitian/Desain Penelitian}

Metode penelitian dalam penelitian ini adalah metode penelitian kuantitatif.

\section{Populasi Penelitian}

Populasi pada penelitian ini adalah seluruh Aparatur Sipil Negara (ASN) di Lembaga Pemasyarakatan Kelas IIA Manado yaitu sebanyak 100 responden dan populasi tersebut akan menjadi sampel dalam penelitian ini.

\section{a. Data Primer}

\section{Teknik Pengumpulan Data}

Sumber data diperoleh dari hasil wawancara menggunakan kuesioner dan pengamatan (observasi) oleh peneliti serta pendokumentasian penelitian.

b.Data Sekunder

Sumber data diperoleh dari Lembaga Pemasyarakatan Kelas IIA Manado berupa Profil kantor berupa distribusi pegawai Aparatur Sipil Negara (ASN) berdasarkan pangkat dan jabatan. 
Teknik pengumpulan data dalam penelitian ini dengan menggunakan kuesioner atau angket. Penelitian ini menggunakan bentuk angket tertutup dengan jawaban yang telah tersedia. Responden akan menerima daftar pertanyaan secara langsung di tempat penelitian. Pertanyaan-pertanyaan tersebut memiliki kaitan dengan kepemimpinan dan motivasi kerja. Data pada penelitian ini berupa data kualitatif yang dikuantitatifkan, sehingga perlu diubah ke dalam bentuk skor, dengan skor sebagai berikut :

a.Jawaban SANGAT SETUJU diberi skor 5

b.Jawaban SETUJU diberi skor 4

c.Jawaban KURANG SETUJU diberi skor 3

d.Jawaban TIDAK SETUJU diberi skor 2

e.Jawaban SANGAT TIDAK SETUJU diberi skor 1

\section{Validitas dan Reliabilitas}

Data merupakan gambaran dari variabel yang diteliti yang berfungsi untuk membuktikan hipotesis, sehingga kebenaran suatu data dapat berpengaruh pada baik tidaknya suatu penelitian.

\section{Validitas}

Validitas adalah untuk mengetahui valid dan sahnya suatu instrument penelitian utuk digunakan. Validitas rendah dapat mempengaruhi instruen yang diguakan. Dua cara untuk mengetahui tingkat validitas instrument yaitu: analisis faktor dan analisis butir. Analisis butir yaitu skor-skor total sebagai nilai $\mathrm{X}$ dan skor total sebagai nilai Y (Arikunto, 2006). Menguji validitas menggunakan aplikasi statistic SPSS. Dengan hasil perhitungan $r$ hitung dibandingkan dengan $\mathrm{r}$ table dengan signifikansi 0.05. jika $\mathrm{r}$ hitung $>\mathrm{r}$ table maka butir pertanyaan pada instrument dikatakan valid, tapi jika $\mathrm{r}$ hitung < $\mathrm{r}$ table makan butir pertanyaan pada instrument dikatakan tidak valid.

\section{Reliabilitas}

Realibilitas diartikan dapat atau tidak dapat dipercayanya penggunaan suatu instrumen enelitian yang akan digunakan sebagai alat untuk mengumpulkan data. (Arikunto, 2006). Jika jawaban responden konsisten dan stabil maka instrument output uji reliabilitas dapat dilihat pada Tabel 1.
Tabel 1. Output Uji Realibilitas Kuisoner

\begin{tabular}{llll}
\hline \multicolumn{3}{c}{ Reliability Statistics } \\
\hline \multicolumn{2}{c}{ Cronbach's Alpha } & Nof Items \\
\hline & .961 & & 45 \\
\hline
\end{tabular}

Berdasarkan Tabel 2 menunjukkan bahwa nilai Cronbach's Alpha 0,961 >0,60 hal ini membuktikan bahwa pertanyaan pada kuisoner dengan tiga variabel sudah reliable dan dapat digunakan sebagai instrument pengumpulan data penelitian.

\section{Konsep Pengukuran Variabel}

Variabel yang ditinjau dalam penelitian ini adalah:

Variabel dalam penelitian ini adalah:

a. Definisi Operasional dan Variabel Penelitian

1) Variabel Kepemimpinan / variabel bebas (X1) dalam penelitian ini kepemimpinan adalah suatu aktivitas yang dilakukan oleh seseorang dalam mempengaruhi tingkah laku orang lain atau kelompok agar bekerja sama di dalam situasi tertentu dalam pencapaian tujuan. Indikator kepemimpinan (X1) adalah :

a) Bersifat adil

b) Memberikan sugesti

c) Mendukung tercapainya tujuan

d) Sebagai katalisator

e) Menciptakan rasa aman

f) Sumber inspirasi

g) Bersifat menghargai (Wahjosumidjo, 1991).

2) Variabel Motivasi Kerja/variabel bebas (X2) dalam penelitian ini adalah suatu perbuatan usaha untuk menggerakkan dan mendorong orang lain agar mereka mau bekerja sama dalam melakukan sesuatu untuk memenuhi kebutuhan yang menjadi tujuannya, sampai kebutuhan itu terpuaskan kemudian digantikan dengan tujuan-tujuan yang lainnya. Indikator dari motivasi ialah:

a) Hubungan dengan rekan kerja dan atasan

b) Lingkungan kerja

c) Kesempatanmeningkatkan pengetahuan dan ketrampilan

d) Pemberian tunjangan. 
3) Variabel Kinerja/variabel terikat (Y) dalam penelitian ini yaitu kinerja adalah hasil kerja secara kualitas dan kuantitas yang dicapai oleh seseorang pegawai dalam melaksanakan tugasnya sesuai dengan tanggung jawab yang duberikan kepadanya (Mangkunegara, 2005) Variabel kinerja ini dapat diukur dari indikator sebagai berikut :
a) Kuantitas
b) Kualitas
c) Ketepatan waktu
d) Kehadiran
e) Kemampuan bekerjasama.

\section{Teknik Analisis Data}

\section{Uji Normalitas}

Uji normalitas digunakan untuk mengetahui distribusi data untuk mengetahui data penelitian pada model statistic, variabel terikat dan variabel bebas berdistribusi normal atau berdistribusi tidak normal. Penggunan statistic parametrik sebagai pengujian apabila data terdistribusi normal, sedangkan pengujian statistic non parametrik apabila tidak terdistribusi normal. Normalitas data dalam penelitian ini dapat diketahui dengan uji normalitas dari masing-masing variabel dengan menggunakan one-sample kolmogorof-smorniv

Untuk menguji normalitas data suatu penelitian, salah satu alat yang digunakan adalah menggunakan uji Kolmogorov Smirnov. Menurut Imam Ghozali (2005), bahwa distribusi data dapat dilihat dengan sebagai berikut:

1. Jika angka signifikansi > taraf signifikansi

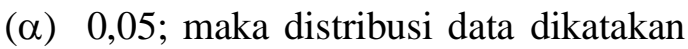
terdistribusi normal.

2. Jika angka signifikansi < taraf signifikansi (a) 0,05 distribusi data dikatakan tidak terdistribusi normal

\section{Uji Multikolinearitas}

Pengujian Multikolinearitas memiliki tujuan untuk mengetahui korelasi antar variabel bebas dalam model regresi. Tidak terjadi korelasi diantara variabel bebas merupakan model regresi yang baik. Variabel-variabel tidak akan orthogonal, jika variabel bebas tidak memiliki korelasi. Variabel orthogonal adalah korelasi sesame variabel bebas sama dengan nol. Nilai tolerance dan Variance Inflation Factor (VIF) menjadi dasar untuk melihat multikoliniearitas. Multikolinearitas bebas dari regresi apabila memiliki nilai toleransi di atas 0,0001 dan VIF kurang dari 5 dan nilai VIF multikolinieritas adalah kurang dari 10 dan tolerance mendekati 1(Santoso, 2000; Ghozali, 2002).

3. Uji Heteroskedastisitas

Hasil uji heteroskedastisitas dapat dilihat dari grafik plot nilai prediksi variabel terikat (ZPRED) dengan residualnya (SRESID). Pendeteksian adanya heteroskedastisitas dapat dilihat dengan ada tidaknya terjadi pola tertentu pada grafik scatterplot antara SRESID dan ZPRED dengan sumbu $\mathrm{Y}$ adalah $\mathrm{Y}$ yang diprediksi dan sumbuh $\mathrm{X}$ adalah residual ( $\mathrm{Y}$ prediksi - Y sessungguhnya) yang sudah di studentized. Jika grafik tidak dalam pola yang jelas, serta titik-titik menyebar di atas dan bawah angka 0 pada sumbuh $\mathrm{Y}$, dapat disebut tidak terjadi heteroskedastisitas.

4. Analisis Regresi Lineer Berganda

Analisis regresi linear berganda digunakan untuk mengetahui bagaimana pengaruh antara variabel bebas dengan variabel terikat yaitu antara variabel kepemimpinan (X1) dan motivasi kerja (X2) terhadap variabel kinerja (Y). Dengan menggunakan rumus sebagai berikut :

$$
\mathrm{Y}=\alpha+\mathrm{b} 1 \mathrm{X} 1+\mathrm{b} 2 \mathrm{X} 2
$$

Keterangan :

$$
\begin{array}{ll}
\mathrm{Y} & =\text { Kinerja } \\
\alpha & =\text { Konstanta } \\
\mathrm{X} 1 & =\text { Kepemimpinan } \\
\mathrm{X} 2 & =\text { Motivasi } \\
\mathrm{b} 1 & =\text { Koefisien Regresi kepemimpinan } \\
\mathrm{b} 2 & =\text { Koefisien Regresi motivasi kerja }
\end{array}
$$

5. Uji Determinasi (r2)

Uji determinasi adalah pengujian untuk mengetahui seberapa besar pengaruh variabel bebas dan variabel terikat. Jika nilai determinasi r2 $=0$, artinya variabel bebas tidak memiliki pengaruh terhadap variabel terikat $(=0 \%)$. Koefisien determinasi $\mathrm{r} 2=1$ artinya variabel bebas berpengaruh terhadap variabel terikat. Sederhannya hasil nilai dari $\mathrm{r} 2$ menjadi besarnya presentasi pengaruh antara variabel bebas X1 dan X2 secara bersama memiliki pengaruh positif dan signifikan terhadap variabel terikat $Y$. 


\section{HASIL DAN PEMBAHASAN}

\section{Hasil Penelitian}

\section{Karakteristik Responden}

Karekteristik responden pada Tabel 2 dapat dilihat untuk kategori pendidikan paling banyak responden berpendidikan SMA berjumlah 65 orang atau $65 \%$ sedangkan responden yang berpendidikan S2 paling sedikit yaitu 3 orang atau $3 \%$. Penelitian yang dilakukan untuk jenis kelamin sebagian responden berjenis kelamin laki-laki yaitu 68 orang atau $68 \%$ dibandingkan dengan responden perempuan hanya 32 orang atau $32 \%$. Data menunjukan untuk kategori umur paling banyak yaitu 31-40 tahun berjumlah 40 orang atau 40 responden sedangkan kategori umur 51-57 tahun paling sedikit yaitu 15 responden atau $15 \%$.

\begin{tabular}{|c|c|c|}
\hline \multicolumn{3}{|c|}{$\begin{array}{l}\text { Distribusi Frekuensi Karakteristik Responden } \\
\text { Aparatur Sipil Negara Lembaga Pemasyarakatan } \\
\text { Kelas IIA Manado }\end{array}$} \\
\hline Karakteristik Responden & Jumlah (Orang) & Persentase (\%) \\
\hline \multicolumn{3}{|l|}{ Pendidikan } \\
\hline SMA & 65 & 65 \\
\hline D3 & 4 & 4 \\
\hline S1 & 29 & 29 \\
\hline S2 & 3 & 3 \\
\hline \multicolumn{3}{|l|}{ Jenis Kelamin } \\
\hline Laki-Laki & 68 & 68 \\
\hline Perempuan & 32 & 32 \\
\hline \multicolumn{3}{|l|}{ Umur } \\
\hline 20-30 Tahun & 27 & 27 \\
\hline 31-40 Tahun & 40 & 40 \\
\hline 41-50 Tahun & 18 & 18 \\
\hline 51-57 Tahun & 15 & 15 \\
\hline
\end{tabular}

\section{Distribusi Frekuensi Variabel Kepemimpinan}

Jawaban terkait dengan pernyataan pimpinan memberikan kesempatan pada semua pegawai untuk mengikuti seleksi jenjang pegawai dengan potensi yang dimiliki oleh pegawai dapat dilihat pada Tabel 3 dengan hasil yang di peroleh jawaban tertinggi responden yang menjawab setuju berjumlah 59 responden atau $59 \%$ dan jawaban sangat tidak setuju tidak ada responden yang menajawab.

Tabel 3. Pemimpin memberikan kesempatan pada semua pegawai untuk mengikuti seleksi jenjang pegawai sesuai dengan potensi yang dimiliki oleh pegawai

\begin{tabular}{ccr}
\multicolumn{2}{c}{ sesuai dengan potensi yang dimiliki oleh pegawai } \\
\hline Jawaban & Jumlah (Orang) & Persentase (\%) \\
\hline SS & 39 & 39 \\
S & 59 & 59 \\
KS & 1 & 1 \\
TS & 1 & 1 \\
STS & 1 & 1 \\
\hline Total & 100 & 100 \\
\hline
\end{tabular}

Tabel 4 menjelaskan bahwa responden yang menjawab pernyataan pimpinan tidak membeda-bedakan antara karyawan yang satu dengan yang lain dalam memberikan tugas yaitu paling banyak setuju berjumlah 64 responden atau $64 \%$ dan untuk sangat tidak setuju tidak ada responden yang menjawab.

Tabel 4. Pimpinan tidak membeda-bedakan antara karyawan yang satu dengan yang lain dalam memberikan tugas

\begin{tabular}{ccr}
\hline Jawaban & Jumlah (Orang) & Persentase $(\%)$ \\
\hline SS & 35 & 35 \\
S & 64 & 64 \\
KS & 0 & 0 \\
TS & 1 & 1 \\
STS & 0 & 0 \\
\hline Total & 100 & 100 \\
\hline
\end{tabular}

Tabel 5 menunjukkan bahwa wawancara yang dilakukan melalui google form terhadap pernyataan pimpinan yang mengadakan seleksi/usulan untuk promosi jabatan secara transparan memiliki jawaban paling banyak setuju berjumlah 68 responden atau $68 \%$ dan untuk pernyataan sangat tidak setuju tidak terdapat jawaban dari responden.

Tabel 5. Pimpinan Mengadakan Seleksi/Usulan untuk Promosi Jabatan Secara Transparan

\begin{tabular}{ccr}
\hline Jawaban & Jumlah (Orang) & Persentase (\%) \\
\hline SS & 25 & 25 \\
S & 68 & 68 \\
KS & 6 & 6 \\
TS & 1 & 1 \\
STS & 0 & 0 \\
\hline Total & 100 & 100 \\
\hline
\end{tabular}

Tabel 6 menunjukkan bahwa untuk pernyataan pimpinan memberikan teladan yang baik dan membagi pengalaman kerjannya jawaban paling banyak setuju berjumlah 61 responden atau $61 \%$ dan untuk tidak setuju dan sangat tidak setuju tidak ada responden yang menjawab.

Tabel 6. Pimpinan Memberikan Teladan yang Baik dan Membagi Pengalaman Kerjanya.

\begin{tabular}{ccr}
\hline Jawaban & Jumlah (Orang) & Persentase (\%) \\
\hline SS & 35 & 35 \\
S & 61 & 61 \\
KS & 4 & 4 \\
TS & 0 & 0 \\
STS & 0 & 0 \\
\hline Total & 100 & 100 \\
\hline
\end{tabular}


Tabel 7 menunjukkan bahwa untuk pernyataan pimpinan memberikan dorongan semangat kerja dalam bentuk apapun kepada pegawainya jawaban paling banyak yaitu setuju berjumlah 66 responden atau $66 \%$ dan untuk sangat tidak setuju tidak ada jawaban dari responden.

Tabel 7. Pimpinan Memberikan Dorongan Semangat Kerja dalam Bentuk Apapun Kepada Pegawainya

\begin{tabular}{ccr}
\hline Jawaban & Jumlah (Orang) & Persentase $(\%)$ \\
\hline SS & 31 & 31 \\
S & 66 & 66 \\
KS & 3 & 3 \\
TS & 0 & 0 \\
STS & 0 & 0 \\
\hline Total & 100 & 100 \\
\hline
\end{tabular}

Tabel 8 untuk pernyataan pimpinan sering memimpin apel satf dan pengamanan paling banyak menjawab setuju berjumlah 69 responden atau $69 \%$ dan untuk sangat tidak setuju tidak ada jawaban dari responden.

Tabel 8. Pimpinan Sering Memimpin Apel Staf dan

\begin{tabular}{ccr}
\multicolumn{2}{c}{ Pengamanan } & \\
\hline Jawaban & Jumlah (Orang) & Persentase (\%) \\
\hline SS & 27 & 27 \\
S & 69 & 69 \\
KS & 4 & 4 \\
TS & 0 & 0 \\
STS & 0 & 0 \\
\hline Total & 100 & 100 \\
\hline
\end{tabular}

Tabel 9 menunjukkan bahwa responden yang memberikan jawaban terkait dengan pimpinan mempunyai inisiatif yang tinggi dalam memberikan ide untuk meningkatkan hasil kerja jawaban paling banyak yaitu setuju berjumlah 69 responden atau $69 \%$ dan untuk jawaban sangat tidak setuju tidak ada jawaban dari responden.

Tabel 9. Pimpinan mempunyai inisiatif yang tinggi dalam memberikan ide untuk meningkatkan hasil kerja.

\begin{tabular}{ccr}
\hline Jawaban & Jumlah (Orang) & Persentase (\%) \\
\hline SS & 26 & 26 \\
S & 69 & 69 \\
KS & 5 & 5 \\
TS & 0 & 0 \\
STS & 0 & 0 \\
\hline Total & 100 & 100 \\
\hline
\end{tabular}

Tabel 10 menunjukkan bahwa pernyataan pimpinan pandai mengadakan pendekatan dalam upaya meningkatkan hasil kerja jawaban paling banyak yaitu setuju berjumlah 60 atau $60 \%$ responden dan untuk sangat tidak setuju tidak ada jawaban dari responden.

Tabel 10. Pimpinan pandai mengadakan pendekatan dalam upaya meningkatkan hasil kerja.

\begin{tabular}{ccr}
\hline Jawaban & Jumlah (Orang) & Persentase (\%) \\
\hline SS & 34 & 34 \\
S & 60 & 60 \\
KS & 6 & 6 \\
TS & 0 & 0 \\
STS & 0 & 0 \\
\hline Total & 100 & 100 \\
\hline
\end{tabular}

Tabel 11 menunjukkan bahwa responden yang menjawab penyataan pimpinan memberikan informasi yang cepat dan jelas dalam pelaksanaan tugas, paling banyak menjawab setuju berjumlah 66 responden atau $66 \%$ dan untuk tidak setuju dan sangat tidak setuju tidak ada jawaban dari responden.

Tabel 11. Pimpinan Memberikan Informasi yang Cepat dan Jelas dalam Pelaksanaan Tugas

\begin{tabular}{ccr}
\hline Jawaban & Jumlah (Orang) & Persentase $(\%)$ \\
\hline SS & 31 & 31 \\
S & 66 & 66 \\
KS & 3 & 3 \\
TS & 0 & 0 \\
STS & 0 & 0 \\
\hline Total & 100 & 100 \\
\hline
\end{tabular}

Tabel 12 menunjukkan bahwa pernyataan pimpinan mengawasi pekerjaan yang dikerjakan oleh pegawainya paling banyak menjawab setuju berjumlah 65 responden atau $65 \%$ dan untuk jawaban tidak setuju dan sangat tidak setuju tidak ada jawaban dari responden.

Tabel 12. Pimpinan Mengawasi Pekerjaan yang Dikerjakan oleh Pegawainya

\begin{tabular}{ccr}
\hline Jawaban & Jumlah (Orang) & Persentase (\%) \\
\hline SS & 29 & 29 \\
S & 65 & 65 \\
KS & 6 & 6 \\
TS & 0 & 0 \\
STS & 0 & 0 \\
\hline Total & 100 & 100 \\
\hline
\end{tabular}




\section{Distribusi Frekuensi Variabel Motivasi Kerja}

Pernyataan jawaban responden tentang hubungan harmonis yang terjalin antara pegawai dan pimpinan ditempat kerja, dapat dilihat pada Tabel 13 dengan hasil yang di peroleh dengan jawaban terbanyak yaitu setuju dengan jumlah 65 responden atau $65 \%$ dan untuk jawaban tidak setuju dan sangat tidak setuju tidak ada responden yang menjawab.

Tabel 13. Hubungan harmonis terjalin antara pegawai dengan pimpinan di tempat kerja.

\begin{tabular}{ccr}
\multicolumn{2}{c}{ pimpinan di tempat kerja. } \\
\hline Jawaban & Jumlah (Orang) & Persentase $(\%)$ \\
\hline SS & 31 & 31 \\
S & 65 & 65 \\
KS & 4 & 4 \\
TS & 0 & 0 \\
STS & 0 & 0 \\
\hline Total & 100 & 100 \\
\hline
\end{tabular}

Pernyataan jawaban responden tentang hubungan unit kerja/organisasi memberikan pendidikan dan pelatihan bagi pegawainnya dapat dilihat pada Tabel 14, jawaban paling banyak setuju berjumlah 59 responden atau $59 \%$ dan untuk sangat tidak setuju tidak ada responden yang menjawab.

Tabel 14. Unit Kerja/ Organisasi memberikan pendidikan dan pelatihan bagi pegawainnya

\begin{tabular}{ccr}
\hline Jawaban & Jumlah (Orang) & Persentase (\%) \\
\hline SS & 49 & 49 \\
S & 51 & 51 \\
KS & 0 & 0 \\
TS & 0 & 0 \\
STS & 0 & 0 \\
\hline Total & 100 & 100 \\
\hline
\end{tabular}

\section{Distribusi Frekuensi Variabel Kinerja}

Pernyataan jawaban responden tentang pekerjaan yang saya hasilkan sudah sesuai dengan target yang ditentukan unit kerja dapat dilihat pada Tabel 15, jawaban paling banyak setuju berjumlah 56 responden atau $56 \%$ dan untuk jawaban tidak setuju dan sangat tidak setuju tidak ada responden yang menjawab.

Tabel 15. Pekerjaan yang saya hasilkan sudah sesuai dengan target yang ditentukan Unit Kerja.

\begin{tabular}{ccr}
\hline Jawaban & Jumlah (Orang) & Persentase (\%) \\
\hline SS & 43 & 43 \\
S & 56 & 56 \\
KS & 1 & 1 \\
TS & 0 & 0 \\
STS & 0 & 0 \\
\hline Total & 100 & 100 \\
\hline
\end{tabular}

Pernyataan jawaban responden tentang saya merasa senang jika dapat mencapai target yang ditetapkan unit kerja dapat dilihat pada Tabel 16, jawaban paling banyak setuju berjumlah 51 responden atau $51 \%$ dan untuk jawaban kurang setuju, tidak setuuju dan sangat tidak setuju tidak ada responden yang menjawab.

Tabel 16. Saya merasa senang jika dapat mencapai target yang ditetapkan unit kerja.

\begin{tabular}{ccr}
\hline Jawaban & Jumlah (Orang) & Persentase $(\%)$ \\
\hline SS & 49 & 49 \\
S & 51 & 51 \\
KS & 0 & 0 \\
TS & 0 & 0 \\
STS & 0 & 0 \\
\hline Total & 100 & 100 \\
\hline
\end{tabular}

\section{Pembahasan}

\section{Karakteristik Responden}

Penelitian yang dilakukan pada Aparatur Sipil Negara di Lembaga Pemasyarakatan Kelas IIA Manado didapatkan untuk karakteristik responden berdasarkan tingkat pendidikan memiliki variasi dimana tingkat pendidikan Sekolah Menengah Atas (SMA) paling banyak yaitu 65 responden, ini disebabkan karena dalam perekrutan CPNS di Kementerian Hukum dan Hak Asasi Manusia khususnya di Lembaga Pemasyarakatan Kelas IIA Manado didominasi dengan formasi SMA yang diperuntukan untuk satuan pengamanan. Sementara untuk tingkat pendidikan Strata 1 (S1) berada pada urutan 2 dengan jumlah 29 orang ini disebabkan untuk Aparatur Sipil Negara di Lembaga Pemasyarakatan Kelas IIA Manado diberikan kesempatan untuk mengembangkan karirnya melalui penyesuian ijazah yang diatur sesuai dengan peraturan yang berlaku di Kementerian Hukum dan HAM sedangkan untuk tingkat pendidikan D3 yang berjumlah 4 orang terdapat pada petugas medis atau perawat serta untuk tingkat pendidikan Strata 2 (S2) paling sedikit yaitu 3 orang ini disebabkan kurangnya beasiswa untuk peningkatan pendidikan di Kementerian Hukum dan HAM dan pada umumnya untuk melanjutkan pendidikan di Strata 1 ataupun 2 menggunakan pembiayaan sendiri.

Karakteristik responden berdasarkan jenis kelamin pada penelitian ini paling banyak adalah laki-laki yaitu berjumlah 68 orang ini disebabkan karena fungsi Lapas Manado yang tugas pokoknya adalah satuan pengamanan terhadap Warga Binaan Pemasyarakatan berjenis kelamin laki-laki 
sedangkan untuk perempuan hanya berjumlah 32 orang ini disebabkan karena untuk Warga Binaan Pemasyarakatan yang berjenis kelamin perempuan telah dipindahkan ke Lembaga Pemasyarakatan Perempuan dan untuk perekrutan kembali Calon Pegawai Negeri Sipil (CPNS) untuk penempatan Lapas Manado sudah dikurangi dan untuk mutasi pegawai staf dari Unit Pelaksana Teknis (UPT) yang lain sudah dibatasi.

Berdasarkan data untuk kategori umur responden paling banyak pada kategori umur 3140 tahun yaitu berjumlah 40 orang dan 20-30 tahun berjumlah 27 orang ini disebabkan karena pada beberapa tahun belakangan ini dari 20062017 dilakukan penerimaan CPNS di Kementerian Hukum dan HAM dan ada yang ditempatkan di Lembaga Pemasyarakatan Kelas IIA Manado sehingga untu kategori umur 20-40 tahun menjadi paling mendominasi Aparatur Sipil Negara di Lapas Manado sedangkan untuk kategori umur 41-50 tahun berjumlah 18 orang dan 51-57 tahun berjumlah 15 orang menjadi kategori umur yang paling sedikit.

Tabel 17. Uji Determinasi Variabel $X_{1}, X_{2}$ dan $Y$

\begin{tabular}{lcccc}
\hline \multicolumn{4}{c}{ Model Summary $^{\mathbf{b}}$} \\
\hline Model & $\mathrm{R}$ & R Square & $\begin{array}{c}\text { Adjusted R } \\
\text { Square }\end{array}$ & $\begin{array}{c}\text { Std. Error of } \\
\text { the Estimate }\end{array}$ \\
\hline 1 & $.586^{\mathrm{a}}$ & .343 & .330 & 5.156 \\
\hline a. Predictors: (Constant), Motivasi Kerja, Kepemimpinan \\
b. Dependent Variable: Kinerja
\end{tabular}

Data yang dianalisis dapat dilihat besar persentase pengaruh variabel kepemimpinan dan variabel motivasi kerja terhadap variabel kinerja Aparatur Sipil Negara dengan uji determinasi. Diketahui pengaruh kepemimpinan dan motivasi kerja terhadap kinerja Aparatur Sipil Negara di Lembaga Pemasyarakatan Kelas IIA Manado sebesar 0,343 atau $34,3 \%$ sedangkan sisanya taitu 0,657 atau $65,7 \%$ dipengaruhi oleh faktor yang lain yang tidak diteliti oleh peneliti seperti disipilin kerja, lingkungan kerja, dan sebagainya. Hasil uji statistik ini diketahui bahwa kepemimpinan dan morivasi kerja memiliki pengaruh terhadap kinerja Aparatur Sipil Negara.
Hasil penelitian ini yang menyatakan kepemimpinan dan motivasi kerja berpengaruh simultan dengan kinerja juga sejalan dengan teori (Badu S dan Djafri N, 2017) yaitu Kepemimpinan dan motivasi kerja merupakan factor penting dalam memengaruhi individu atau kelompok untuk mengidentifikasi tujuannya dan meningkatkan kinerjanya dalam rangka mencapai tujuan yang ditetapkan organisasi.

Observasi dan wawancara yang dilakukan melalui google formulir didapatkan bahwa Aparatur Sipil Negara di Lembaga Pemasyarakatan Kelas IIA Manado terkait dengan variabel kepemimpinan terdapat beberapa responden yang kurang setuju dan tidak setuju dengan cara kepemimpinan yang dilakukan oleh pemimpin namun tidak menjadi menjadi suatu pengaruh untuk mempengaruhi kinejanya, sama halnya dengan variabel motivasi kerja terdapat beberapa Aparatur Sipil Negara di Lembaga Pemasyarakatan Kelas IIA Manado masih belum termotivasi dengan hal-hal yang diberikan organisasi untuk peningkatan kinerjanya. Namum secara umum terkait kepemimpinan dan motivasi kerja Aparatur Sipil Negara berpendapat setuju dan sangat setuju dengan cara kepemimpinan dan motivasi kerja yang diberikan pimpinan dan organisasi untuk peningkatan kinerja pegawainya dalam pencapaian tujuan organisasi.

\section{KESIMPULAN DAN SARAN}

1. Kepemimpinan

\section{Kesimpulan}

Kepemimpinan berpengaruh positif terhadap Kinerja Apatur Sipil Negara di Lembaga Pemasyarakatan Kelas IIA Manado dengan nilai koefisien regresi 0.034, sehingga semakin baik kepemimpinan maka akan semakin baik kinerja.

2. Motivasi kerja

Motivasi kerja berpengaruh positif terhadap Kinerja Aparatur Sipil Negara di Lembaga Pemasyarakatan Kelas IIA Manado dengan nilai koefisien regresi 0,742, sehingga semakin baik motivasi kerja maka akan semakin baik kinerja. 


\section{Kepemimpinan}

Berkaitan dengan kepemimpinan diharapkan dapat memberikan promosi jabatan secara terbuka dan sesuai ketentuan peraturan yang berlaku serta berdasarkan kompetensi, lebih aktif dalam memberikan pengarahan melalui kegiatan-kegiatan rapat/ briefing dan dapat meningkatkan dalam pendekatan kepada bawahan dengan memimpin apel staf dan pengamanan serta memberikan edukasi kepada seluruh pegawai terkait dengan penggunaan aplikasiaplikasi yang digunakan dalam kedinasan.

2. Motivasi Kerja

Motivasi kerja dibutuhkan peran pimpinan yang aktif dalam memberikan reward bagi pegawai yang berkinerja baik dengan pemberian penghargaan yang menarik perhatian pegawai dan dapat memfasilitasi tempat kerja yang nyaman agar bawahan dapat bekerja dengan penuh semangat serta peningkatan dalam operasional perjalanan dinas pegawai.

\section{DAFTAR PUSTAKA}

Arikunto. 2006. Prosedur Penelitian Suatu Pendekatan Praktik. Jakarta: Rineka Cipta.

Badu S dan Djufri N, 2017. Kepemimpinan dan Perilaku Organisasi. Gorontalo. Ideas Publishing.

Daftar Inventaris Masalah (DIM). 2020. Lembaga Pemasyarakatan Kelas IIA Manado. Manado.

Ghozali, Imam. 2006. Aplikasi Analisis Multivariate dengan Program SPSS. Semarang: BP UNDIP.

Inspektorat Jenderal Kemenkumham (Itjen). 2020. Berita Acara Evaluasi Komponen Pengungkit dan Komponen Hasil Satuan Kerja Berpredikat Menuju WBK/WBBM Tahun 2020 pada Lembaga Pemasyarakatan Kelas IIA Manado. Jakarta.

Kementerian Pendayagunaan Aparatur Negara dan Reformasi Birokrasi. 2019. Hasil Evaluasi Zona Integritas Menuju WBK/WBBM. Jakarta.

Mangkunegara A. 2005. Evaluasi kinerja sumberdaya manusia. Jakarta: Revika Aditama. 